\title{
Why Am I Alone? [A Short Communication]
}

\author{
Angela Brown \\ E-mail: brownlas6@aol.com
}

Doi:10.7575/aiac.alls.v.5n.4p.22

URL: http://dx.doi.org/10.7575/aiac.alls.v.5n.4p.22
Received: 04/04/2014

Accepted: 05/06/2014

\section{Chapter One: Mr. Charming}

In deep thought, scandalous feelings found its true meaning that let to disappointment. Keith was my boy. My eyes would focus on his charming personality that would lead to what I deserved. Keith was an alcoholic. He would drink under stress. I worried about his problem. He never considered drinking as a problem. Instead, drinking was an alibi to cover his emotions away from confronting his feelings about women. Keith was diagnosed as a manic depressive and he refused to seek treatment. His mother always felt that family came first and if her son was out of line, he would turn to ma for comfort. Keith was a Mama's boy. She would not let anything come between their relationships. This made Keith sensitive of what others thought about him. Keith was very paranoid and was concerned whether people liked him. His image was important to him. He wanted to be liked. Keith's father was abusive and neglected his son. Keith told me stories about how his father beat him repeatedly for no reason. He felt he could never live up to his father's expectations. This made Keith suicidal.

Janet fell in love with Keith for his moral support. Janet felt when Keith was around, he became her security blanket. Her world began to diminish as long as he was there for her. He supported her dreams of being a nurse. He wanted her to complete college. Keith was a college dropout; but he believed in Janet. There love began to blossom as he would stole in the park with her, stranded at her window, recited excerpts of poems to her which was impressive. Keith was a mechanic with the dream of owning his own shop. Janet worked hard in school. Keith worked hard in building their relationship. But would this be enough?

Keith was the answer to her problems with men. Although he was obese, he cared about his appearance. He did the right things. He ate right. He exercised. He was vulnerable to Janet. Their relationship was a fairy tale, where she found prince charming. Their relationship was so close, they could not get enough of each other's friendship. That's it. Their relationship was based on their friendship.

In their relationship, they promised to be celibate. She thought nothing more than being friends. She did not want to jeopardize how she felt. It would break their friendship apart.

Time passed and she was ready to graduate from college. Just when she thought she met the perfect man he began to become over protective of her. He had an insecurity knowing he was not the right economic status for her and they would never marry. Keith began to ask questions: Where did you go? When will you come back? Who will you be with? This carried on for months, until he held his hand up at her. Janet knew she would never allow a man to hit her, so she voted out of this climate for a better life.

\section{Chapter Two: Maintenance Man}

Jade lived a good life. She had a good job, an overpriced townhouse, and was financially established. After her grandmother died, she left Jade a trust. Jade's mother held a secret life as a stripper and a cocaine addict. Her mother was faced with the reality that she could not be the mother for Jade, while her boyfriend lived the life as a junkie. Jade was given up for adoption when her grandmother decided to raise Jade.

Kiel was amazingly sharp with a remarkable sex appeal. Jade always was found of his acquaintance. Jade's mom knew their bond would hit it off. Kiel appeared to be more sensitive than most men. He loved to share his feelings with her. They would talk for hours at a time about nothing in particular. Kiel became her best friend. She felt she trusted Kiel with her inner deep thoughts and secrets.

Kiel was a social butterfly. Kiel was a delightful personality whose influence could charm a crowed, met every women's secret desire. Jade was taken by his looks most of all. Kiel could tell Jade the latest fashions. He knew how to put a wardrobe together with style. He kept her coordinated. He knew how she should wear her hair. He knew all women's trends. He could look at a woman's jewelry and tell her what to wear. Kiel knew the right things to tell Jade to build her self-esteem. Jade needed this in a man. A man that made her feel good about herself that she kept in good company.

Kiel was a male model-T. He was a maintence man on the side. Jade like a man who could come around to fix things up. He was found to look at as well. He was a man on the move. Jade was surprise he had no interest in other women. Jade knew her roots. Kiel was different. She always wondered why he paid so much attention to her. Kiel was dependable to her when she cried. She found herself spending all her time who cared more for his appearance than her wellbeing.

Jade noticed this about Kiel. He limited his time with her to spending time with the guys. At the start of their friendship she noticed he had an eye for men. He thought he wanted to feel pretty to impress other men. Kiel would look up and down women to find his attraction for gay men. 
Jade and Kiel spent a lot of free time together that was limited to taking back commitment in a relationship to establish a friendship that prepared Jade to love herself. Jade was barely an adult and had time to grow spiritually the love that was promised to her from God.

\section{Chapter Three: The Charmer}

Steven was the trigger Tina starved for. Steven gave Tina the ride she always wanted. Steven was a great father figure. The same father figure Tina found in her father. When Tina found Steven, he kept her in good company. Nowhere else she knew a man like this one.

Steven had a kid. He was a single father whose mother died after he was born and father abandoned Steven as a child, leaving him to be raised by faster parents. His mom made Steven feel insecure like no one ever loved or cared for him. As a father, Steven was destined to be better than the life he had for his son.

Steven wanted a mother for his child. Steven was on drugs. He would spend his work income on drugs. His girlfriend was an addict and did not want her child. This meant to Steven that he had to take the responsibility of raising his son as a single parent. He wanted a mother for support because he knew a two parent home is the best love he could have in a family to provide for his son.

Tina felt being a mother would not be a problem, because Steven loved her. To show she cared for Steven, Tina would spend time caring for his son. Tina would cook, clean and play with his son for what it seemed like eternity. She spent more time with his son than the time they spent getting acquainted. It seems that Steven depended on her to raise his son for her. Tina began to get overwhelmed to the point that their relationship was manipulated and was centered around raising Steven's child.

The child was named Oscar. He was a good boy and he wanted a mother more than anything. Tina wondered how his biological mom could desert her own child. In the dead heat, she abandoned her son for drugs. Steven deep inside stood his ground that he did not want to lose his son. The love between father and son, deeply moved Tina and she knew she could not hurt either one of them.

Tina spent so much time being a loyal friend to Steven that she forgotten about her own feelings. She no longer had the time to do things for herself. The love Tine once had for them began to turn to hate. She began to get angry with herself for not being true to her needs. Tina needed to breathe. She wanted a child of her own. She was hurt she could not have this with Steven. She wanted a family. She needed Steven to help be the father he claimed to be. When Steven refused to do this, the violence raged between them. Tina began to get rebellious demanding Steven's time and affection that she most needed and when he told her he could not give one hundred percent, she left him. She knew if she looked back, she would regret it.

\section{Chapter Four: Mr. Flirt}

Kay was a very strong woman for what she had to deal with. She was a mother of six children, and a single mother. Kay worked two jobs to keep her life sorted. She had shown that she cared for her children most of all; but she needed a provider to help support her emotionally and provided for the family. Kay worked very hard with three jobs. She was a physician assistant, an office assistant and on call. Kay had her children as a young teenage mother. She got a GED, studied in college and was a college graduate. Kay worked very hard for her children. Her family was absent of a father figure.

Devin was retired general from the army. Devin was dark, tall and handsome. He was a six pack, was very mineable and had his way with women. He was cleverly educated, economically influenced and committed to a relationship with his wife. Davin was the most handsome man Kay had ever seen from the inside out. He would take Kay to the Jazz clubs, the gospel fest and the college ballet. Devin was truly a ladies man and a smooth talker. Kay could not know how she would do without him.

Devin's wife was dying of cancer. Devin was searching for the love his wife could not give him. Kay was attentive, affectionate and compromising to Devin. It was what he needed in a relationship, between relationships of losing his one true love of his life.

There was a problem with Devin and Kay's relationship. There was me, he and she and Kay knew inside that she had his affection; but, she could not win his love. Kay relied heavily on instant on how to keep Devin from making her weak. Kay had to face a reality that she fell in love with a married man who were good with her and her children that she could not share.

Devin never had kids with his wife. The demand of having a family would break him of his man hood. Devin had a very negative view about children. Surely he was great with kids. Devin hated his father for giving him everything. He felt neglected like his father never cared to spend time with him. Kay felt weak in the abuse and affection he had on her kids. Kay felt sad that every time he consented with her girls she was engrossed with pain. Kay's soul was searching for the person who left her to raise her kids alone and she found this with Devin. Devin was no different than her children's father. Would she ever recover that there is nothing you can do with a married man.

After Devin's wife died, he became very depressed. Devin began to open up to Kay and wanted her in his life more than ever. Kay love for him was unconditional. She knew she was not his first love. She knew how he treated her children. He was abusive to her girls. Kay knew that when making a family, everything comes in a package. Devin must change his ways to show devotion to her in order to be a family. As long as Devin, would not meet Kay half way, he could not win her family's love. Kay decided that true love is more than what is inside her heart; but what comes with the territory. Kay decided to return to her life as a single mom was the most important gift she could give to her children than a father that does not love them.

\section{Chapter Five: Fatal Attraction}

Liz had a lot of bad relationships in her life. She was sexually abducted as a child. She was a child. A child of God who had to learn how to forgive.

Nathen was an actor. He could convince anyone of any lie he told. Liz like everyone else believed in Nathen. She was so caught up in their love affair she became the lie he told. She became one with him. 
Nathen was abusive mentally and physically to Liz. Liz was blind and could not see that because of her insecurity from her past, she thought when Nathen abused her that he loved her. Nathen became controlling of her. Nathen cheated on Liz. Their marriage meant more than anything. During Liz parents' generation a marriage was binding and so she forgave Nathen time after time after time.

Nathen would come up with excuses for not loving Liz. He would tell her she was too fat, too ugly, and too dumb for him. Nathen would claim the other women could satisfy him more than his wife. Nathen had a high powered job. Men would sleep with him for a promotion. Liz knew this; but prayed to God he would change. Liz thought because he slept with her that he loved her and saw something special in her.

When Nathen told Liz he did not love her any more, this broke her heart. Liz had been supportive of Nathen's job until he made a profitable career. Nathen made it clear to Liz he wanted her to stay at home, to cook, to clean. He controlled her life. He did not want her to spend money to get her hair done or nails done and not to buy clothes. It appeared to other women she never cared for herself. She was hurt she could not have any children for his infidelity to her. It was then he began to look at other women. He flirted with women in her presence. Liz was dependent on Nathen and her family knew this. Liz thought that if she divorced him she would be thought of in a negative way, in that she was not a good wife for the church. Nathen refused Liz to have friends.

Nathen possessed the infinite, flawless skin of a white man. He was gentle, kind, affectionate and even sensitive. When Liz met Nathen, he made an impressionable church nerd appearance to her parents and friends. Nathen was very athletic and an over achiever. Liz was a book worm. Her instructors felt she would be a positive influence in society someday. It had been close to a year they dated. People would whisper as she passed. The gossip was that Nathen had lots of women interested in him. Liz family knew this; but kept it a secret for Liz would be broken hearted. Liz ran away from home and stopped college to marry Nathen. He swept her off her feet. Because he paid her some attention, she thought she was in love.

When Liz met Nathen, the world stopped turning. Liz eloped behind her parents to marry Nathen. Liz parents never granted her consent in marriage. Liz did not have the consent from the church. A few minutes alone turned into hours at a time when Liz left Nathen for infidelity. Liz knew this could never be. She could either leave him or die incomplete.

ALONE, By Angela Brown

The lessons we encounter are phases that prepare us for our journey. There are six shelves in the morality of life:

Chapter Six: Life Shelves

There are phases in life that we must encounter which prepares us for our spiritual journey. Each phase is a shelf of knowledge we must use as a testimony of faith. Through all the tyranny of being deceived, there is compassion and hope with the ones who mean the most and matter the most to us. We must find our need to discover our self-worth and to excel in life.

Shelf one. There is emptiness. A hallow ground, where life is incomplete. Searching for answers to why no one ever cared.

Shelf two. There is bitterness. Life is controlling. There is a feeling there is no way out of it. You are committed.

Shelf three. There is self-hate. Everything you thought you wanted in life, you do not deserve. You wanted to earn love.

Shelf four. There is denial. You are not happy with life. You are not happy with whatever you do. You do not know what you want out of life.

Shelf five. You are in transition. When you think you are satisfied, something is wrong. You must escape before it hurts you. 